\title{
KARET ALAM EPOKSI SEBAGAI BAHAN BAKU PEMBUATAN KOMPONEN KARET PADA KATUP TABUNG DAN REGULATOR LPG
}

\author{
Epoxidized Natural Rubber as Raw Material for Manufacturing Rubber Components \\ in Tube Valve and Regulator of LPG
}

Hani HANDAYANI*, M. Irfan FATURROHMAN, Norma A. KINASIH, dan Asron F. FALAAH

Pusat Penelitian Karet

Jalan Salak Nomor 1 Bogor 16151 Jawa Barat

*Email: hani.ppkbogor@gmail.com

Diterima : 9 Januari 2018 / Disetujui : 15 Februari 2018

\begin{abstract}
The trend of declining natural rubber prices in the last 5 years has encouraged the diversification of natural rubber-based products, one of which is rubber components in tube valve and regulator of LPG. Manufacture of rubber components for tube valve and regulator of $L P G$ has been using synthetic rubber with polar properties. Synthetic rubber NBR has good resistance to $L P G / n$-pentane, while natural rubber is easy to swells in oil. The epoxidation of the double bond of natural rubber molecule is an effort to increase its polarity. The purpose of this research was to increase natural rubber consumption by substitution of synthetic rubber with epoxidized natural rubber. The concentrated latex was diluted and reacted with performic acid at $70^{\circ} \mathrm{C}$ for 5 hours then neutralized, coagulated, creped, and dried. The epoxidized natural rubber was then used for compounding of rubber components in tube valve and regulator of LPG and then tested according to the requirements in SNI 7655: 2010 about rubber seals. The results showed that epoxidized natural rubber-based compound fulfilled the requirements of SNI. Thus, epoxidized natural rubber could be used as raw material for rubber components manufacture in tube valve and regulator of $L P G$.
\end{abstract}

Keywords: Natural rubber; epoxidized natural rubber; LPG; NBR substitution; regulator; valve

\begin{abstract}
Abstrak
Tren penurunan harga karet alam dalam 5 tahun terakhir mendorong diversifikasi produk berbasis karet alam, salah satunya adalah komponen karet pada katup tabung dan regulator LPG. Pembuatan komponen karet untuk katup dan regulator LPG selama ini masih menggunakan karet sintetis yang memiliki sifat polar. Karet sintetik NBR memiliki ketahanan yang baik terhadap LPG/n-pentana, sedangkan karet alam mudah mengembang dalam minyak. Epoksidasi ikatan rangkap molekul karet alam merupakan upaya untuk meningkatkan polaritasnya, sehingga ketahanannya terhadap minyak serta beberapa sifat fisiknya meningkat. Tujuan dari penelitian ini adalah meningkatkan konsumsi karet alam dengan cara substitusi karet sintetik (NBR) dengan karet alam epoksi. Lateks pekat diencerkan kemudian direaksikan dengan asam performat pada suhu $70^{\circ} \mathrm{C}$ selama 5 jam kemudian dinetralkan, digumpalkan, digiling krep, dan dikeringkan. Karet alam epoksi yang diperoleh selanjutnya digunakan untuk formulasi komponen karet pada katup tabung dan regulator gas LPG dan diuji sesuai persyaratan di dalam SNI 7655:2010 tentang rubber seal. Hasil penelitian menunjukkan bahwa kompon berbasis karet alam epoksi memenuhi persyaratan SNI. Dengan demikian karet alam epoksi dapat digunakan sebagai bahan baku pembuatan komponen karet pada katup tabung dan regulator LPG.
\end{abstract}

Kata kunci: Karet alam; karet alam epoksi; katup; LPG; regulator; substitusi NBR 


\section{PENDAHULUAN}

Karet alam merupakan salah satu komoditas perkebunan yang sangat penting dalam menunjang perekonomian Indonesia karena berperan sebagai sumber devisa negara dari sektor non migas. Data tahun 2014 menunjukkan luas areal tanaman karet di Indonesia adalah seluas 3,61 juta Hektar dan menempati areal perkebunan terluas ketiga setelah kelapa sawit dan kelapa. Indonesia menjadi negara kedua produsen karet terbesar di dunia setelah Thailand, yang produksinya tahun 2014 mencapai 3,15 juta ton (Direktorat Jenderal Perkebunan [Ditjenbun], 2016). Sebagai negara produsen karet alam terbesar kedua di dunia, Indonesia memiliki potensi yang besar menjadi pengendali pasar karet alam dalam negeri. Langkah-langkah yang dapat ditempuh diantaranya melalui pengembangan produk karet untuk industri barang jadi karet alam serta diversifikasi produk karet alam selain ban.
Program konversi minyak tanah ke LPG yang dilakukan oleh Pemerintah sejak tahun 2007 telah berhasil melakukan penghematan subsidi sebesar IDR 197,05 triliun (Kementerian Energi dan Sumber Daya Mineral (ESDM], 2016). Selain penghematan energi, program ini mendorong perekonomian masyarakat dengan tumbuhnya industri kompor, katup, tabung, selang, dan regulator LPG. Berdasarkan data dari Kementerian ESDM tahun 2010, kebutuhan tabung LPG seluruh Indonesia sebanyak 100 juta tabung berukuran $3 \mathrm{~kg}$ mendorong berkembangnya industri kompor LPG, katup, tabung, selang dan regulator dalam negeri (ESDM, 2016). Berkembangnya industri katup, regulator dan selang LPG mendorong meningkatnya kebutuhan bahan-bahan untuk pembuatan katup, regulator dan selang LPG. Salah satu bahan yang terdapat pada ketiga produk tersebut adalah komponen karet. Komponen karet yang terdapat di dalam regulator dan katup tabung gas LPG disajikan pada Gambar 1.

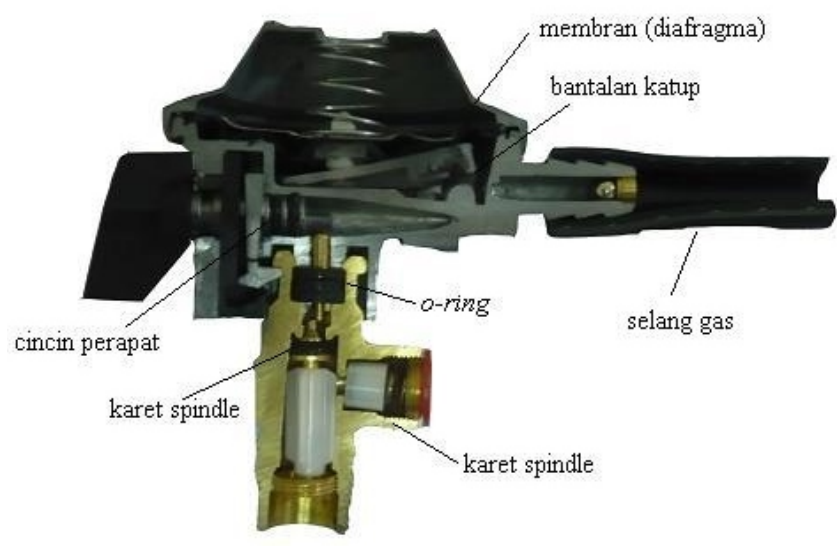

Gambar 1. Komponen karet di dalam regulator dan katup tabung gas LPG

Figure 1. Rubber component in a regulator and tube valve of $L P G$

Komponen karet yang terdapat di dalam katup tabung terdiri dari rubber seal (karet perapat) dan karet spindle. Sementara pada regulator terdapat beberapa komponen karet, diantaranya: o-ring, bantalan katup, dan membran (diafragma) sedangkan komponen yang menghubungkan antara regulator dan kompor adalah selang karet. Komponen-komponen karet tersebut sebagian besar berkontak langsung dengan gas LPG, sehingga harus memiliki ketahanan terhadap gas LPG yang baik agar tidak mengalami penurunan kualitas produk. Berdasarkan SNI rubber seal (SNI 7655:2010) dan SNI selang karet (SNI 067213-2006), ketahanan rubber seal dan selang karet terhadap gas LPG dapat didekati dengan pelarut $n$-pentana untuk lebih memudahkan uji laboratorium. Oleh karena itu setiap komponen karet yang terdapat pada katup, regulator dan selang karet harus memiliki ketahanan yang unggul terhadap pelarut $n$-pentana. 
Saat ini, industri komponen karet untuk katup dan regulator menggunakan karet sintetik yang memiliki sifat polar salah satunya adalah karet Nitrile Butadiene Rubber (NBR) yang diimpor dengan harga di pasar domestik sebesar USD 2,50 - 3,65 per Kg. Karet NBR memiliki ketahanan yang baik terhadap oli dan pelarut non polar (Choi \& Ha, 2009; Wang et al., 2014), dimana ketahanannya meningkat seiring peningkatan kandungan akrilonitrilnya (Sommer, 2009). Sedangkan karet alam murni bersifat non polar dan apabila berkontak dengan pelarut non polar akan mengalami pengembangan (swelling), sehingga dapat menurunkan kualitas dari produk karet untuk komponen karet pada katup dan regulator LPG. Oleh karena itu pemakaian karet alam murni tidak bisa digunakan untuk komponen karet untuk katup dan regulator.

Karet alam mengandung sekitar 15.000-20.000 ikatan tidak jenuh pada rantai molekulnya. Disamping itu, karet alam bersifat non polar, sehingga karet alam tidak tahan terhadap minyak (Phinyocheep $\&$ Boonjairaak, 2006). Salah satu upaya untuk meningkatkan ketahanan terhadap minyak pada karet alam adalah dengan melakukan modifikasi secara kimia terhadap karet alam melalui reaksi epoksidasi. Reaksi epoksidasi pada karet alam akan menghasilkan suatu cincin epoksida pada rantai polimer karet alam.
Reaksi epoksidasi dapat dibuat dalam fase lateks atau dengan menggunakan pelarut organik. Reaksi epoksidasi yang dibuat pada fase lateks lebih praktis dan ekonomis daripada dengan menggunakan pelarut organik karena penggunaan pelarut organik disamping mahal juga akan bermasalah terhadap lingkungan.

Reaksi epoksidasi merupakan reaksi antara karet dengan perasam. Asam perasetat dan asam performat banyak digunakan sebagai reaktan untuk reaksi epoksidasi pada fase lateks karet alam (Phinyocheep \& Boonjairaak, 2006). Tetapi reaksi epoksidasi karet alam menggunakan asam performat yang dihasilkan dari hidrogen peroksida dan asam format secara in situ lebih mudah untuk digunakan (Phinyocheep, Phetphaisit, Derouet, Campistron, \& Brosse, 2005), karena reaksi epoksidasi dengan menggunakan asam performat tidak memerlukan asam sulfat sebagai katalis (Gambar 2).

Karet alam epoksidasi adalah salah satu karet yang memberikan beberapa sifat yang lebih baik pada vulkanisat seperti ketahanan terhadap minyak yang lebih baik, ketahanan pantul dan permeasi gas yang lebih rendah daripada karet alam (Eng, Tanaka, \& Gan, 1997). Kegunaan karet alam terepoksidasi adalah untuk membuat barang jadi karet tahan minyak, tahan benturan, perekat, dan pelapis PVC.

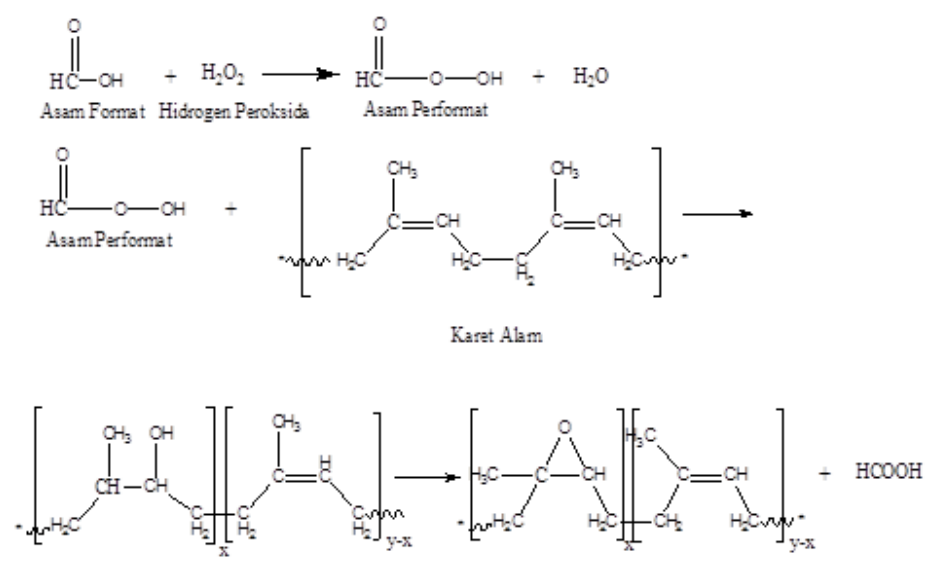

Gambar 2. Reaksi epoksidasi karet alam

Figure 2. Epoxidation reaction of natural rubber 
Tujuan dari penelitian ini adalah meningkatkan konsumsi karet alam dengan cara substitusi karet sintetik NBR dengan karet alam epoksi yang digunakan untuk pembuatan komponen karet pada katup tabung dan regulator LPG. Implementasi hasil penelitian ini diharapkan dapat meningkatkan penguasaaan teknologi pembuatan karet alam epoksi sebagai bahan baku komponen karet pada katup dan regulator LPG sehingga dapat meningkatkan konsumsi dalam negeri sekaligus meningkatkan nilai tambah karet alam dan diharapkan dapat menciptakan lapangan kerja baru.

\section{BAHAN DAN METODE}

Kegiatan penelitian ini dilaksanakan dari bulan Maret hingga Oktober 2017 bertempat di Pusat Penelitian Karet, Bogor Jawa Barat dan PT. Mitra CMB, Tangerang Banten. Kegiatan pembuatan karet alam epoksi, komponding, dan pengujian dilakukan di Laboratorium Penelitian, Pabrik Percobaan, dan Laboratorium Penguji Pusat Penelitian Karet. Sementara kegiatan pencetakan produk dilakukan di PT. Mitra CMB, Tangerang.

Bahan yang digunakan dalam penelitian ini terdiri dari bahan untuk pembuatan karet alam epoksi dan bahan kimia komponding karet. Bahan pembuatan karet alam epoksi meliputi: lateks karet alam segar (lateks kebun) yang diperoleh dari Perkebunan Karet Rakyat Jasinga Kabupaten Bogor, lateks pekat dari supplier lokal, surfaktan emulgen $20 \%$ dari PT. KAO Indonesia, asam format $90 \%$, hidrogen peroksida $50 \%$, ammoniak, dan natrium tiosulfat yang diperoleh dari supplier lokal. Adapun bahan kimia komponding karet meliputi: sulfur, asam stearat, seng oksida, bahan pengisi meliputi silika, kaolin, kalsium karbonat, dan carbon black, antiozonan (antilux), cross linker (vulcuren), white factice, bahan pencepat meliputi CBS (Cyclohexyl Benzothiazole Sulfenamide), TMTD (Tetramethyl Thiuram Disulfide), dan DTDM (Dithio Dimorpholine), bahan antioksidan meliputi TMQ (Trimethyl Dihydroquinoline) dan MMB (Mercaptomethyl
Benzimidazole); pigmen pewarna meliputi merah, kuning, jingga, dan titanium oksida, silane Si-69 (Bis-Triethoxy Silyl PropylTetrasulfide), rhenofit (Triallyl Cyanurate Silica), serta plasticizer DOP (Dioctyl Phthalate).

Peralatan penelitian meliputi tangi deamoniasi reaktor pembuatan karet epoksi kapasitas $5 \mathrm{~kg} /$ batch, beakerglass dan plat pemanas (hot plate) Gilingan kreper untuk membuat karet krep dan untuk pengeringannya digunakan oven. Peralatan untuk karakterisasi spektrum FTIR berupa spektrofotometer FTIR Thermo Scientific Nicolet iS5. Peralatan untuk preparasi kompon berupa mesin gilingan terbuka (open mill), serta Rheometer MDR 2000 untuk pengujian sifat vulkanisasi.

Kegiatan dalam penelitian ini diawali dengan pembuatan karet alam epoksi kemudian penentuan persen mol epoksi yang dihasilkan menggunakan spektrofotometer FTIR. Setelah didapat karet alam epoksi dengan kandungan persen epoksi sebesar $40 \%$ kemudian dilakukan formulasi dengan menyusun 3 buah kompon hitam berdasarkan 3 tingkat kekerasan (Shore A) yaitu hardness 60 untuk kompon O-ring dan membran, hardness 70 untuk kompon karet spindle, dan hardness 80 untuk kompon bantalan katup, serta 1 kompon berwarna untuk kompon rubber seal. Formula kompon hitam dirinci dalam Tabel 1, sedangkan formula kompon warna disajikan dalam Tabel 2. Semua kompon tersebut kemudian diuji sesuai persyaratan SNI 7655:2010 tentang rubber seal dan selanjutnya dicetak menjadi produk di PT. Mitra CMB. Produk yang diperoleh selanjutnya diuji ketahanannya di dalam pelarut $n$-pentana.

\section{Pembuatan Karet Alam Epoksi}

Sebanyak 3,5 L lateks pekat diencerkan hingga kadar karet kering (KKK) $20 \%$ kemudian ditempatkan di dalam reaktor berkapasitas $5 \mathrm{~kg} /$ batch. Selanjutnya ke dalam lateks ditambahkan emulgen sebanyak 4 bsk untuk mencegah penggumpalan. Reaksi epoksidasi dijalankan dengan menambahkan asam 
Tabel 1. Susunan resep kompon hitam komponen karet pada katup dan regulator LPG Table 1. Black compound receipt for rubber components in valve and regulator of LPG

\begin{tabular}{|c|c|c|c|c|}
\hline \multirow{2}{*}{ No. } & \multirow{2}{*}{$\begin{array}{l}\text { Bahan } \\
\text { Materials }\end{array}$} & \multicolumn{3}{|c|}{$\begin{array}{l}\text { Jumlah (berat seratus karet, bsk) } \\
\text { Dosage (per hundered rubber, phr) }\end{array}$} \\
\hline & & Kompon A & Kompon B & Kompon C \\
\hline 1. & ENR & 100 & 100 & 100 \\
\hline 2. & Carbon black N550 & 30 & 40 & \\
\hline 3. & Carbon black N774 & 30 & 40 & \\
\hline 4. & Carbon black N330 & & & 30 \\
\hline 5. & Antilux & 2 & 2 & 2 \\
\hline 6. & TMQ & 2 & 2 & \\
\hline 7. & MMB & & & 2 \\
\hline 8. & DOP & 6 & 8 & 3 \\
\hline 9. & Seng oksida & 5 & 5 & 3 \\
\hline 10. & Asam stearat & 1 & 1 & 1 \\
\hline 11. & CBS & 1,5 & 1,5 & 2 \\
\hline 12. & TMTD & 2,5 & 2,5 & 1 \\
\hline 13. & DTDM & 1 & 1 & \\
\hline 14. & Sulfur & 0,3 & 0,3 & 0,6 \\
\hline 15. & Vulcuren & 1 & 1 & 1 \\
\hline 16. & White factice & 5 & 5 & 5 \\
\hline 17. & Kalsium karbonat & 5 & 5 & 5 \\
\hline
\end{tabular}

Tabel 2. Susunan resep kompon untuk rubber seal LPG Table 2. Compound receipt for rubber seal of $L P G$

\begin{tabular}{clc}
\hline No. & \multicolumn{1}{c}{$\begin{array}{c}\text { Bahan } \\
\text { Materials }\end{array}$} & $\begin{array}{c}\text { Jumlah (berat seratus karet, bsk) } \\
\text { Dosage (per hundered rubber, phr) }\end{array}$ \\
\hline 1. & ENR & 100 \\
2. & Silika 175MP & 30 \\
3. & Kaolin & 20 \\
4. & Silane & 3 \\
5. & Rhenofit & 3 \\
6. & Pigmen merah & 0,375 \\
7. & Pigmen kuning & 0,165 \\
8. & Pigmen jingga & 1,505 \\
9. & Titanium oksida & 4,11 \\
10. & Antilux & 2 \\
11. & MMB & 2 \\
12. & DOP & 8 \\
13. & Vulcuren & 1 \\
14. ZnO & 5 \\
15. & Asam stearat & 2 \\
16. & CBS & TMTD \\
17. & DTDM & 4,5 \\
18. & STDlfur & 2 \\
19. & Sulfur & 3 \\
& & 0,3 \\
\hline
\end{tabular}


format sebanyak $0,4 \mathrm{~mol} / \mathrm{mol}$ unit isoprena dan hidrogen peroksida sebanyak 0,75 mol/mol isoprena unit. Campuran direaksikan hingga mencapai suhu $70 \mathrm{C}$. Titik nol penghitungan waktu reaksi dimulai ketika semua bahan selesai ditambahkan. Selanjutnya reaksi dijalankan selama 5 jam hingga terbentuk lateks epoksi dengan kadar $40 \%$.

\section{Analisis Persen Terepoksidasi}

Persen lateks terepoksidasi dapat dihitung secara kuantitatif menggunakan data dari spektrum FTIR dengan cara menghitung absorbansi dari pita karaktristik untuk cincin epoksida pada bilangan gelombang $870 \mathrm{~cm}^{-1}$, cincin terbuka pada bilangan gelombang $3.460 \mathrm{~cm}^{-1}$, gugus $-\mathrm{CH}_{3}$ dari karet alam pada bilangan gelombang $1375 \mathrm{~cm}^{-1}$ serta olefin yang tidak termodifikasi pada bilangan gelombang 835 $\mathrm{cm}^{-1}$. Rumus untuk menghitung persen karet yang terepoksidasi (E) dan persen cincin terbuka (R) menurut Chakraborty, Kar, Ameta, Dasgupta dan Mukhopadhyay (2010) adalah sebagai berikut:

$\mathrm{E}=\frac{100 \times K_{1} \times A_{870 \text { corr. }}}{A_{835}+K_{1} \times A_{870 \text { corr. }}+K_{2} \times A_{3460} \text { corr. }}$

dan

$R=100-E-\left(\frac{A_{835}}{K_{1}} \times \frac{E}{A_{870 \text { corr. }}}\right)$

Keterangan (Remaks):

$\mathrm{E}=$ persen mol lateks terepoksidasi

$\mathrm{R}=$ persen $\mathrm{mol}$ cincin oksiran yang terbuka

$\mathrm{A}_{870 \text { corr. }}=\mathrm{A}_{870}-0,14 \times \mathrm{A}_{835}$

$A_{3460 \text { corr. }}=A_{3460}-0,019 \times A_{1375}$

3. Pembuatan dan Karakterisasi Vulkanisat

Karet alam epoksi yang berhasil diperoleh selanjutnya digiling dengan bahan-bahan kimia komponding karet di dalam open mill sesuai dengan resep kompon (Tabel 1 dan Tabel 2). Kompon karet alam epoksi tersebut kemudian divulkanisasi hingga membentuk vulkanisat di dalam mesin press vulkanisasi pada suhu $150^{\circ} \mathrm{C}$ selama waktu tertentu sesuai dengan hasil
Rheometernya yang diukur dengan alat Rheometer MDR 2000. Vulkanisat yang terbentuk kemudian diuji beberapa parameter sifat fisika seperti kekerasan, kuat tarik, perpanjangan putus, pampatan tetap, ketahanan pengusangan, dan ketahanan dalam n-pentana sesuai SNI 7655:2010 tentang rubber seal.

\section{Pengujian Ketahanan terhadap n-} Pentana

Pengujian ini mengacu pada ISO 1817 , sampel uji berupa kompon dan produk direndam di dalam cairan $n$-pentana selama 168 jam pada suhu $27 \pm 2$ C. Setelah perendaman sampel uji dikeringkan pada suhu $70 \pm 2$ C selama 4 hari, kemudian diukur kembali perubahan volumenya setelah pengeringan. Perubahan volume dihitung sesuai dengan persamaan berikut :

$\Delta V=\left[\left(\frac{m_{i}-m_{i, w}+m_{s, w}}{m_{0}-m_{o, w}+m_{s, w}}\right)-1\right] \times 100$

Keterangan (Remaks):

$\Delta \mathrm{V} \quad$ : perubahan volume

$\mathrm{m}_{0}$ : massa contoh uji mula-mula di udara

$\mathrm{m}_{\mathrm{i}}$ : massa contoh uji setelah perendaman

$\mathrm{m}_{0, \mathrm{w}}$ :massa contoh uji mula-mula (ditambah pemberat jika digunakan) dalam air

$\mathrm{m}_{\mathrm{i}, \mathrm{w}}$ : massa contoh uji (ditambah pemberat jika digunakan) setelah direndam dalam air

$\mathrm{m}_{\mathrm{s}, \mathrm{w}}$ : massa pemberat, jika digunakan, di dalam air

\section{HASIL DAN PEMBAHASAN}

\section{Pembuatan Karet Alam Epoksi}

Reaksi epoksidasi dalam penelitian ini menggunakan pereaksi hidrogen peroksida dan asam format untuk menghasilkan asam performat. Asam format dipilih karena tidak memerlukan katalis. Optimasi telah dilakukan untuk menentukan kondisi optimum dengan melakukan epoksidasi pada variasi jenis lateks, dosis asam format, dan metode penambahan hidrogen peroksida. Jumlah hidrogen peroksida dibuat tetap pada dosis optimal sesuai 
dengan hasil penelitian Kinasih dan Fathurrohman (2016) yaitu sebanyak 0,75 $\mathrm{mol} / \mathrm{mol}$ isoprena unit.

Pembuatan karet epoksi skala semi pilot dengan kapasitas $5 \mathrm{~kg}$ / batch dilakukan dalam sebuah reaktor berpengaduk yang dijalankan menggunakan oli sebagai pemanas pada suhu $70^{\circ} \mathrm{C}$ selama 5 jam. Reaktor dilengkapi dengan sistem pendingin yang berfungsi untuk menjaga agar temperatur selama reaksi konstan. Sistem pendingin diperlukan karena reaksi epoksidasi merupakan reaksi eksotermis. Media pendingin yang digunakan adalah air yang disirkulasi.

Analisis kadar epoksi karet alam dilakukan dengan menggunakan spektrofotometri infra merah atau FTIR (Fourier Transform Infra Red). Terjadinya epoksidasi dapat terlihat dari pita karakteristik pada bilangan gelombang 870 $\mathrm{cm}^{-1}$ yang karakteristik untuk cincin epoksi, produk pembukaan cincin pada bilangan gelombang $3460 \mathrm{~cm}^{-1}$, dan cincin olefin yang tidak mengalami modifikasi pada bilangan gelombang $837 \mathrm{~cm}^{-1}$ (Chakraborty et al., 2010).
Analisis gugus fungsi berdasarkan spektrum FTIR karet terepoksidasi hasil penelitian ini menunjukkan pita karakteristik untuk cincin epoksida pada bilangan gelombang $870 \mathrm{~cm}^{-1}$ semakin tinggi intensitasnya yang berarti cincin epoksida yang terbentuk semakin banyak. Sementara itu puncak olefin yang tidak termodifikasi pada bilangan gelombang $835 \mathrm{~cm}^{-1}$ semakin menurun intensitasnya dibandingkan dengan spektrum FTIR karet alam yang berarti sebagian besar gugus olefin dari karet alam telah mengalami modifikasi menjadi gugus epoksi (Gambar 3). Hasil perhitungan berdasarkan spektrum FTIR, pada kondisi optimum diperoleh karet alam epoksi dengan kandungan epoksi 44,13\% yang diperoleh setelah reaksi selama 5 jam.

\section{Pembuatan dan Karakterisasi Vulkanisat}

Karet epoksi yang diperoleh dari reaksi skala semi pilot selanjutnya digunakan untuk membuat kompon untuk komponen karet pada katup dan regulator LPG. Vulkanisat kompon kemudian diuji sesuai SNI 7655:2010 tentang rubber seal. Data hasil uji vulkanisat dari kompon tersebut disajikan pada Tabel 3.

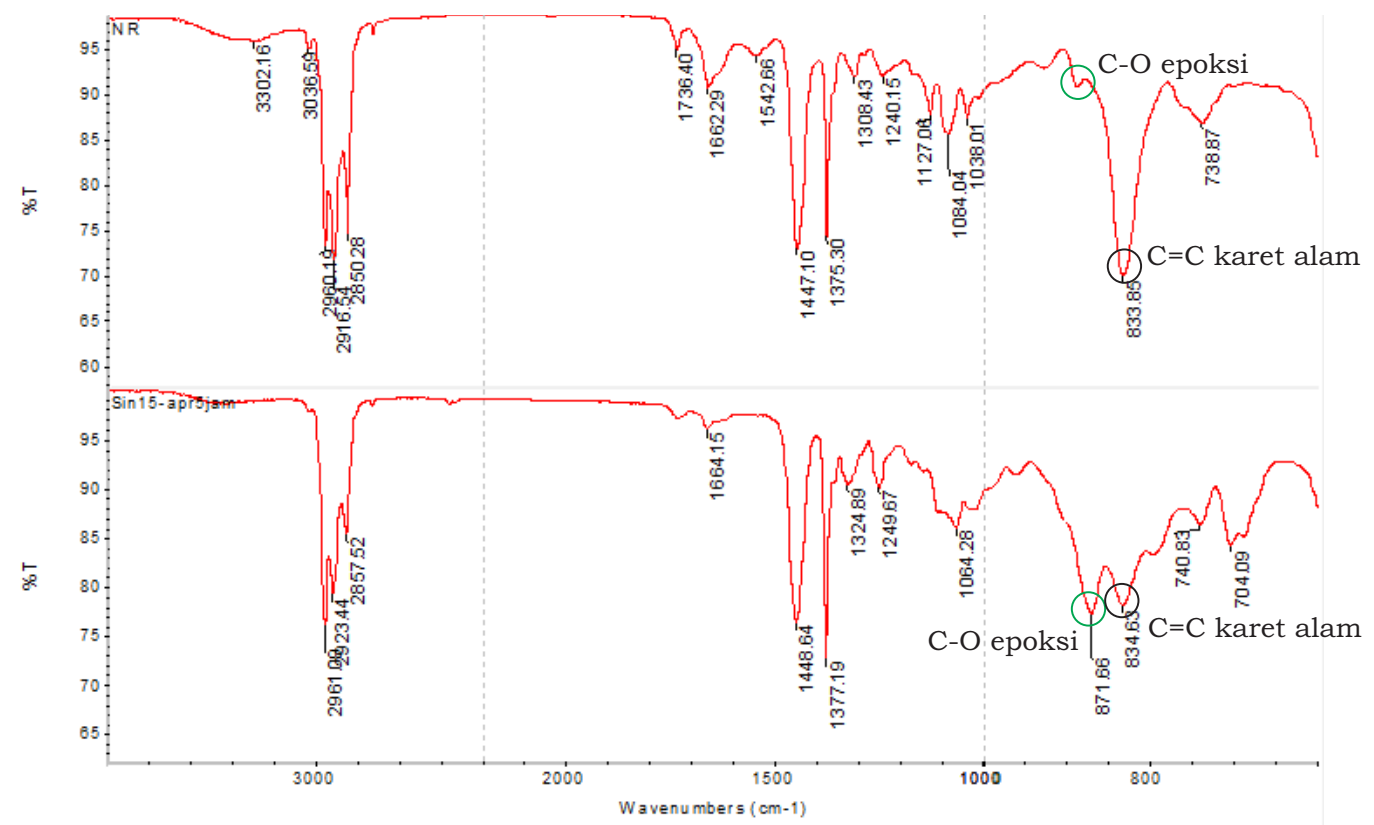

Gambar 3. Perbandingan spektrum FTIR karet alam murni (atas) dengan epoksi (bawah) Figure 3. Comparison of FTIR spectras of pure natural rubber (above) and epoxidized (below) 
Hasil pengujian ketiga kompon hitam yang disajikan pada Tabel 3 menunjukkan bahwa untuk kompon A dan $\mathrm{C}$ seluruh parameter sudah memenuhi persyaratan SNI 7655:2010. Kekerasan untuk kompon hitam A sengaja dibuat di atas 70, melebihi standar SNI, karena kompon tersebut ditujukan untuk membuat karet spindle yang membutuhkan karakter karet yang sedikit lebih keras dibandingkan karet seal sebab dalam aplikasinya akan mengalami tekanan oleh katup regulator. Sementara itu fomula kompon hitam B dibuat dengan kekerasan yang lebih tinggi dibandingkan kompon A dan C karena ditujukan untuk pembuatan karet bantalan katup yang dalam aplikasinya digunakan sebagai bantalan untuk katup regulator sehingga diperlukan karakter karet yang lebih keras dibandingkan karet seal dan karet spindle.

Untuk mendapatkan kompon dengan kekerasan yang tinggi maka diperlukan lebih banyak bahan pengisi.
Jumlah pengisi yang lebih banyak cenderung menyebabkan penurunan sifat fisik vulkanisat karet diantaranya perpanjangan putus dan kuat tarik (Herminiwati \& Lestari, 2009). Hal tersebut sesuai dengan hasil yang disajikan pada Tabel 3 dimana untuk kompon B, nilai perpanjangan putus dan kuat tarik setelah pengusangan tidak memenuhi persyaratan SNI 7655:2010. Namun hal tersebut dianggap tidak terlalu berpengaruh terhadap fungsi dari bantalan katup yang dalam aplikasinya tidak membutuhkan sifat elastis karena hanya digunakan sebagai bantalan.

Sementara itu kompon C merupakan kompon yang ditujukan untuk membuat komponen karet lain yang ada di dalam katup dan regulator LPG yaitu membran dan O-ring. Hasil pengujian pada Tabel 3 menunjukkan bahwa kompon tersebut sudah memenuhi persyaratan SNI 7655:2010 tentang rubber seal.

Tabel 3. Hasil uji vulkanisat A, B, dan C sesuai SNI 7655:2010

Table 3. Result of A, B, and C vulcanizates testing based on SNI 7655:2010

\begin{tabular}{|c|c|c|c|c|}
\hline \multirow{2}{*}{$\begin{array}{l}\text { Sifat fisik } \\
\text { Physical properties }\end{array}$} & \multirow{2}{*}{$\begin{array}{l}\text { Syarat mutu } \\
\text { Requirement }\end{array}$} & \multicolumn{3}{|c|}{$\begin{array}{l}\text { Vulkanisat } \\
\text { Vulcanizate }\end{array}$} \\
\hline & & A & $\mathrm{B}$ & $\mathrm{C}$ \\
\hline Kekerasan, Shore A & $60 \pm 5$ & 71 & 82 & 60 \\
\hline Kuat tarik, Mpa & Min. 10 & 14,6 & 15,3 & 13,6 \\
\hline Perpanjangan putus, \% & Min. 300 & 350 & 270 & 360 \\
\hline \multicolumn{5}{|l|}{ Pampatan tetap, \% } \\
\hline 72 jam (3 hari) pada $(27 \pm 2)^{\circ} \mathrm{C}$ & Maks. $10 \%$ & 5,90 & 8,27 & 6,14 \\
\hline 72 jam $\left(3\right.$ hari) pada $(? 5 \pm 2)^{\circ} \mathrm{C}$ & Maks. 25\% & 2,6 & 5,39 & 1,96 \\
\hline \multicolumn{5}{|l|}{$\begin{array}{l}\text { Pengusangan pada suhu }(70 \pm 2)^{\circ} \mathrm{C} \text { selama } 168 \\
\text { jam, perubahan nilai setelah pengusangan }\end{array}$} \\
\hline Kekerasan, Shore A & \pm 10 & 2 & 3 & 5 \\
\hline Kuat tarik, \% & \pm 15 & 11,64 & 15,03 & 9,56 \\
\hline Perpanjangan putus / elongation at break, \% & $+10,-25$ & $-14,28$ & $-22,22$ & $-19,44$ \\
\hline \multicolumn{5}{|l|}{$\begin{array}{l}\text { Perubahan volume dalam cairan ( } n \text {-pentana), \% } \\
\text { Setelah } 168 \text { jam ( } 7 \text { hari) pada }(27 \pm 2)^{\circ} \mathrm{C}\end{array}$} \\
\hline Setelah 96 jam (4 hari) dikeringkan pada & Maks. +35 & 33,92 & 24,26 & 19,98 \\
\hline$(70 \pm 2)^{\circ} \mathrm{C}$ & Maks. -12 & $-0,82$ & $-6,17$ & $-6,94$ \\
\hline $\begin{array}{l}\text { Ketahanan terhadap ozon }(50 \pm 5) \text { pphm, } \\
(40 \pm 2)^{\circ} \mathrm{C},(55 \pm 10) \% \mathrm{RH},(20 \pm 2) \% \text { perpanjangan, } \\
\text { pretension time } 72 \text { jam, exposure time } 48 \text { jam }\end{array}$ & Tidak retak & $\begin{array}{l}\text { Tidak } \\
\text { retak }\end{array}$ & $\begin{array}{l}\text { Tidak } \\
\text { retak }\end{array}$ & $\begin{array}{l}\text { Tidak } \\
\text { retak }\end{array}$ \\
\hline
\end{tabular}


Sementara itu untuk kompon rubber seal, karena produknya tidak berwarna hitam sehingga formulanya berbeda dengan 4 produk lainnya yang menggunakan formula kompon hitam. Sebanyak 1 formula kompon rubber seal telah dibuat, komposisi formula tersebut disajikan dalam Tabel 2 dan hasil pengujian sifat fisika kompon tersebut dapat dilihat pada Tabel 4.

Data pada Tabel 4 menunjukkan bahwa hampir seluruh parameter uji sampel rubber seal telah memenuhi persyaratan SNI 7655:2010 tentang rubber seal kecuali untuk parameter pampatan tetap yang nilainya sedikit lebih besar dari standar mutu yang ditetapkan dalam SNI. Semakin besar nilai pampatan tetap menunjukkan bahwa setelah dipampatkan elastisitas karet semakin berkurang (Handayani, Faturrohman, \& Kuncoro, 2011). Reformulasi masih diperlukan untuk menyempurnakan formulasi tersebut sehingga semua parameter dapat memenuhi persyaratan SNI.

Keempat kompon yang telah diuji tersebut kemudian dicetak menjadi produk di PT. Mitra CMB. Gambar kelima prototipe produk komponen karet yang terdapat di dalam katup tabung dan regulator LPG dapat dilihat pada Gambar 4. Hasil pengujian ketahanan terhadap $n$-pentana untuk produk-produk tersebut dapat dilihat pada Tabel 5.

Tabel 4. Hasil uji vulkanisat kompon rubber seal sesuai SNI 7655:2010

Table 4. Result of rubber seal vulcanizate testing based on SNI 7655:2010

\begin{tabular}{|c|c|c|}
\hline $\begin{array}{c}\text { Sifat fisik } \\
\text { Physical properties }\end{array}$ & $\begin{array}{l}\text { Syarat mutu } \\
\text { Requirement }\end{array}$ & $\begin{array}{l}\text { Hasil } \\
\text { Value }\end{array}$ \\
\hline Kekerasan (Shore A) & $60 \pm 5$ & 60 \\
\hline Kuat tarik/tensile strength (Mpa) & Min. 10 & 10 \\
\hline Perpanjangan putus / elongation at break (\%) & Min. 300 & 350 \\
\hline $\begin{array}{l}\text { Pampatan tetap/ compression set }(\%) \\
72 \text { jam (3 hari) pada }(27 \pm 2)^{\circ} \mathrm{C} \\
72 \text { jam }\left(3 \text { hari) pada }(? 5 \pm 2)^{\circ} \mathrm{C}\right.\end{array}$ & $\begin{array}{l}\text { Maks. 10\% } \\
\text { Maks. 25\% }\end{array}$ & $\begin{array}{c}12,27 \\
6,51\end{array}$ \\
\hline $\begin{array}{l}\text { Pengusangan pada suhu }(70 \pm 2)^{\circ} \mathrm{C} \text { selama } 168 \text { jam, } \\
\text { perubahan nilai setelah pengusangan (heat ageing) } \\
\text { Kekerasan (Shore A) } \\
\text { Kuat tarik/tensile strength (\%) } \\
\text { Perpanjangan putus/ elongation at break }(\%)\end{array}$ & $\begin{aligned} & \pm 10 \\
& \pm 15 \\
+ & 10, ? 25\end{aligned}$ & $\begin{array}{c}2 \\
-4,00 \\
-14,29\end{array}$ \\
\hline $\begin{array}{l}\text { Perubahan volume dalam cairan ( } n \text {-pentana) }(\%) \\
\text { Setelah } 168 \text { jam }\left(7 \text { hari) pada }(27 \pm 2)^{\circ} \mathrm{C}\right. \\
\text { Setelah } 96 \text { jam }\left(4 \text { hari) dikeringkan pada }(70 \pm 2)^{\circ} \mathrm{C}\right. \\
\text { Ketahanan terhadap ozon }(50 \pm 5) \text { pphm, }(40 \pm 2)^{\circ} \mathrm{C} \text {, } \\
(55 \pm 10) \% \mathrm{RH},(20 \pm 2) \% \text { perpanjangan, pretension time } \\
72 \text { jam, exposure time } 48 \text { jam }\end{array}$ & $\begin{array}{l}\text { Maks. }+35 \\
\text { Maks. }-12\end{array}$ & $\begin{array}{l}30,17 \\
-9,87\end{array}$ \\
\hline
\end{tabular}




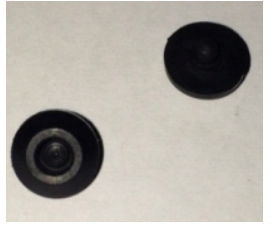

(a)

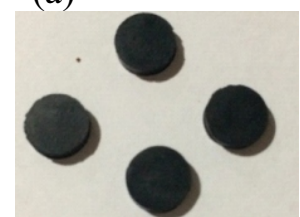

(d)

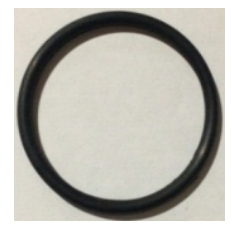

(b)

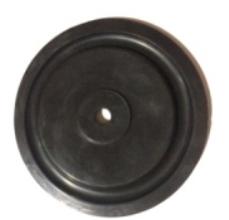

(c)

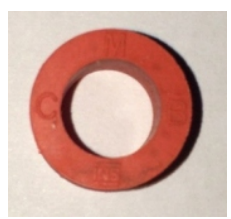

(e)

Gambar 4. Prototipe produk komponen karet pada katup tabung dan regulator LPG: (a) karet spindle, (b) O-ring, (c) membran, (d) bantalan katup, dan (e) rubber seal

Figure 4. Product prototype of rubber components in tube valve and regulator of LPG: (a) spindle rubber, (b) O-ring, (c) membrane, (d) valve pad, and (e) rubber seal

Tabel 5. Hasil pengujian ketahanan terhadap n-pentana dari produk komponen karet pada katup dan regulator gas LPG

Table 5. Result of resistance in n-pentane from product prototype of rubber components in tube valve and regulator $L P G$

\begin{tabular}{|c|c|c|c|c|c|c|}
\hline \multirow{2}{*}{$\begin{array}{c}\text { Sifat fisik } \\
\text { Physical properties }\end{array}$} & \multirow{2}{*}{$\begin{array}{l}\text { Syarat mutu } \\
\text { Requirement }\end{array}$} & \multicolumn{5}{|c|}{$\begin{array}{c}\text { Produk komponen karet } \\
\text { Rubber components }\end{array}$} \\
\hline & & $\begin{array}{l}\text { Bantalan } \\
\text { Katup }\end{array}$ & $\begin{array}{c}\text { Karet } \\
\text { Spindle }\end{array}$ & O-Ring & $\begin{array}{l}\text { Rubber } \\
\text { Seal }\end{array}$ & $\begin{array}{l}\text { Membran } \\
\text { Membrane }\end{array}$ \\
\hline \multicolumn{7}{|l|}{$\begin{array}{l}\text { Perubahan volume dalam } \\
\text { cairan ( } n \text {-pentana) }(\%)\end{array}$} \\
\hline $\begin{array}{l}\text { Setelah } 168 \text { jam (7 hari) } \\
\text { pada }(27 \pm 2)^{\circ} \mathrm{C}\end{array}$ & Maks. +35 & 24,26 & 33,92 & 19,98 & 22,41 & 22,86 \\
\hline $\begin{array}{l}\text { Setelah } 96 \text { jam (4 hari) } \\
\text { dikeringkan pada }(70 \pm 2)^{\circ} \mathrm{C}\end{array}$ & Maks. -12 & $-6,17$ & $-0,82$ & $-6,94$ & $-11,94$ & $-4,88$ \\
\hline
\end{tabular}

Dari data pada Tabel 5 dapat dilihat bahwa semua prototipe produk memiliki ketahanan yang cukup baik di dalam $n$ pentana sehingga memenuhi persyaratan SNI. Dengan demikian karet alam epoksi dapat digunakan sebagai bahan baku pembuatan komponen karet pada katup tabung dan regulator LPG menggantikan karet sintetik (NBR).

\section{KESIMPULAN}

Berdasarkan hasil penelitian yang dilakukan, dapat disimpulkan bahwa:

Pembuatan karet alam epoksi menggunakan reaktor yang telah dirancang pada tahun sebelumnya menghasilkan karet alam epoksi dengan persen mol epoksi sebesar $44,13 \%$.
Hasil pengujian sifat fisika kompon berbahan baku karet alam epoksi untuk komponen karet pada regulator dan katup tabung LPG berupa bantalan katup, karet spindle, o-ring, dan membran telah memenuhi persyaratan SNI 7655:2010 tentang rubber seal. Sementara itu, khusus untuk kompon rubber seal masih belum memenuhi persyaratan untuk parameter pampatan tetap sehingga masih diperlukan penyempurnaan.

Hasil pengujian ketahanan produk di dalam $n$-pentana menunjukkan ketahanan yang baik karena memenuhi persyaratan SNI. Dengan demikian karet alam epoksi dapat digunakan sebagai bahan baku pembuatan komponen karet pada katup tabung dan regulator LPG menggantikan karet sintetik NBR. 


\section{UCAPAN TERIMA KASIH}

Ucapan terima kasih disampaikan kepada PT. Mitra CMB, Tangerang atas kesediaannya mencetak prototipe produk komponen karet dalam katup tabung dan regulator LPG dalam penelitian ini. Terima kasih dan penghargaan turut disampaikan kepada Kemenristekdikti atas bantuan dana penelitian melalui program Insentif Riset Sistem Inovasi Nasional (Insinas) Tahun Anggaran 2017.

\section{DAFTAR PUSTAKA}

Badan Standarisasi Nasional. (2006). SNI 067213-2006 tentang selang karet untuk kompor gas LPG. Jakarta, Indonesia : BSN.

Badan Standarisasi Nasional. (2010). SNI 7655:2010 tentang karet perapat (rubber seal) pada katup tabung LPG. Jakarta, Indonesia : BSN.

Chakraborty, S., Kar, S., Ameta, R., Dasgupta, S., \& Mukhopadhyay, R. (2010). Quantitative application of FTIR in rubber, dikutip dalam Rubber World: The Technical Service Magazine for The Rubber Industry, 241, 34.

Choi, S., \& Ha, S. (2009). Influence of the swelling temperature and acrylonitrile content of NBR on the water swelling behaviors of silica-filled NBR vulcanizates. Journal of Industrial and Engineering Chemistry, 15(2), 167-170. Doi : 10.1016/j.jiec.2008.09.016.

Direktorat Jenderal Perkebunan. (2016). Statistik Perkebunan Indonesia: Karet 2015-2017. Jakarta, Indonesia: Sekretariat Direktorat Jenderal Perkebunan, Kementerian Pertanian [Ditjenbun].
Eng, A.H., Tanaka, Y., \& Gan, S.N. (1997). Some properties of epoxidised deproteinised natural rubber. Journal of Natural Rubber Research, 12(2), 8289.

Handayani, H., Fathurrohman, M.I., \& Kuncoro, I. (2011). Karakteristik sifat fisik dan ketahanan terhadap minyak dari karet alam epoksi. Jurnal Penelitian Karet, 29(1), 49-62. Doi : 10.22302/ppk.jpk.v29i1.111

Herminiwati., \& Lestari, S.B.P. (2009). Pengaruh penambahan bahan pengisi aluminium silikat dan bahan pengembang azodicarbonamide dalam pembuatan karet mikroseluler untuk sol ringan. Majalah Kulit, Karet, dan Plastik, 25(1), 31-38. Doi : 10.20543/mkkp.v25i1.230

Kementerian Energi dan Sumber Daya Mineral. (2016, 25 Desember). Konversi minyak tanah ke LPG menggerakkan perekonomian, menghemat energi. Diakses dari https:/ / www.esdm.go.id

Kinasih, N.A., \& Fathurrohman, M.I. (2016). Pengaruh kondisi reaksi terhadap karakteristik ketahanan karet alam epoksi dalam n-pentana. Jurnal Sains Materi Indonesia, 17(3), 102-109.

Phinyocheep, P., Phetphaisit, C.W., Derouet, D., Campistron, I., \& Brosse, J.C. (2005). Chemical degradation of epoxidized natural rubber using periodic acid: preparation of epoxidized liquid natural rubber. Journal of Applied Polymer Science, 95, 6-15. Doi : 10.1002/app. 20812

Phinyocheep, P., \& Boonjairak, K. (2006). Investigation on Hydrogenation and Epoxidation of Natural Rubber in Latex Stage. Proceedings of international rubber conference 2006. Lyon, France: CIRAD-IRRDB 
Sommer, J.G. (2009). Engineered rubber products: introduction to design, manufacture and testing. Munchen, Jerman: Carl Hanser Verlag.
Wang, H., Lu, X., \& Wang, S. (2014). The swelling properties of nitrile rubber with different acrylonitrile contents in cyclohexane medium research. Advanced Materials Research, 936, $1942-1947$. D o i 10.4028/www.scientific.net/AMR.936 .1942 